DOI : $10.14746 /$ ps.2017.1.35

\title{
Sprawozdanie z XXVI Międzynarodowej Konferencji Bezpieczeństwa Ameryka i bezpieczeństwo euroatlantyckie - ustanawiając nowy porzq̨dek?, Kraków, 27 marca 2017 r.
}

27 marca 2017 r. odbyła się XXVI Międzynarodowa Konferencja Bezpieczeństwa zorganizowana przez Fundację Instytut Studiów Strategicznych, Kwaterę Glówną NATO oraz Fundację Konrada Adenauera.

Otwierając konferencję A. Szymańska-Klich, Prezes Fundacji ISS, sformulowala pytania dotyczące współczesnej sytuacji bezpieczeństwa na świecie, majace posłużyć jako impulsy do dyskusji w trakcie konferencji: jaka będzie polityka bezpieczeństwa administracji Donalda Trumpa? Czy uspokajające deklaracje wiceprezydenta M. Pence'a i sekretarza obrony J. Mattisa nie zostaną unieważnione jednym tweetem ich przełożonego? Czy zostanie zawiazane porozumienie pomiędzy USA a Rosją i rozpocznie się nowy koncert mocarstw i polityka stref wplywów?

Panel pierwszy poświęcono nowej polityce zagranicznej USA i jej wplywowi na NATO, koncentrując uwagę na priorytetach, możliwościach i finansowaniu. W dyskusji udzial wzięli: Marek Świerczyński (Polityka Insight) jako moderator oraz Robert Nurick (Atlantic Council), Marco Overhaus (SWP), Roman Kuźniar (UW), Dominique David (IFRI) oraz Mieczyslaw Cieniuch (general Sil Zbrojnych RP w stanie spoczynku, b. szef Sztabu Generalnego Wojska Polskiego, b. ambasador RP w Ankarze).

Prezentując perspektywę amerykańską, R. Nurick zauważyl, że po uplywie dwóch miesięcy od inauguracji D. Trumpa nadal występowalo wiele wątpliwości co do kształtu polityki nowego prezydenta - np. w związku z wciąż nieobsadzonymi stanowiskami w jego administracji. R. Nurick ocenił proces przejmowania wladzy jako bardzo powolny i chaotyczny. W opinii prelegenta można optymistycznie postrzegać ksztaltowanie nastawienia administracji D. Trumpa wobec europejskich sojuszników z NATO, przede wszystkim ze względu na osoby J. Mattisa i H. R. McMastera - silne osobowości w administracji nowego prezydenta, prezentujace ustabilizowane poglądy na partnerstwo transatlantyckie. Niepokojące zapowiedzi D. Trumpa na ten temat z kampanii wyborczej będą także, zdaniem R. Nuricka, temperowane przez opór ze strony Kongresu. Stawiany przez D. Trumpa wymóg większego zaangażowania finansowego Europy w NATO jest według prelegenta „kwestią możliwą do rozwiązania” (ang. managable issue). Według R. Nuricka bardziej niepokojący jest stosunek nowej amerykańskiej administracji wobec Ukrainy - niewiadomą pozostaje stopień i charakter zaangażowania USA w sytuację w tym państwie. Bilateralne relacje Stanów Zjednoczonych z Rosją mogą stać się bardziej kooperatywne np. w zakresie zwalczana tzw. Państwa Islamskiego, jednak różnice w interesach i priorytetach mogą utrudniać osiagnnięcie porozumienia. R. Nurick poruszył także aspekt broni jądrowej zauważając sprzeczne sygnaly dobiegające z Białego Domu dotyczące zarówno rozbudowy, jak i ograniczania arsenału nuklearnego. Starając się nakreślić perspektywę uznał, iż chociaż nie ma powodu do paniki, to dalszy proces ksztaltowania się nowej polityki zagra- 
nicznej USA będzie nieprzewidywalny i skomplikowany ze względu na osobowość i styl nowego amerykańskiego prezydenta.

Marco Overhaus podkreślil, że naciski na zwiększenie przez państwa europejskie nakładów na obronność do poziomu $2 \%$ PKB oraz groźby ograniczenia amerykańskiego zaangażowania w NATO mają duży wplyw na debatę publiczną w Niemczech. Wedhug niego występuje dwoistość oczekiwań D. Trumpa wobec sojuszników europejskich: zarówno zwiększenia finansowania, jak i wypełnienia luki po zmniejszeniu wydatków USA na polu niemilitarnych aspektów bezpieczeństwa. Te nowe tendencje niosą dla państw europejskich wedlug M. Overhausa zarówno ryzyko, jak i szansę na rozszerzenie perspektywy i kontekstu debaty na temat bezpieczeństwa. Zapytany przez moderatora o gotowość Niemiec do przejęcia większej odpowiedzialności w zakresie bezpieczeństwa, M. Overhaus zauważył trwający w RFN proces zwiększania wydatków na obronność i intensyfikacji debaty na temat zaangażowania Niemiec na tym polu, która jednak nadal ma pewne ograniczenia.

R. Kuźniar rozpocząl swoje wystapienie od zdecydowanego stwierdzenia, iż na wynik wyborów amerykańskich w dużym stopniu wplynęła Rosja zgodnie z zasadą: ,jeżeli nie możesz ich pokonać - wybierz im swojego prezydenta", starając się uderzyć w największą silę Sojuszu, czyli jego wewnętrzną jedność i solidarność. Prelegent określil podejście D. Trumpa do polityki zagranicznej jako komercyjne, rynkowe oraz silnie antyeuropejskie, co czyni z niego niepewnego sojusznika w trudnych czasach. Następnie R. Kuźniar krytycznie odniósł się do niedawnej publikacji Zbigniewa Brzezińskiego, w której postulował on utworzenie przez USA triady militarnych liderów światowych wraz z Rosją i ChRL. Takie rozwiązanie z pewnością ucieszyłoby Rosję oraz oznaczaloby swoiste porzucenie NATO i ograniczenie jego roli w ksztaltowaniu globalnego bezpieczeństwa.

D. David zaprezentował podejście bardziej stonowane wobec polityki zagranicznej nowego prezydenta USA zauważając, że pomimo, iż dodaje on niepewności do sytuacji, to jednak nie zmienia radykalnie „regul gry” ze względu na znaczenie NATO jako narzędzia wplywu politycznego. Nowe okoliczności powinny, zdaniem D. Davida, przekonać UE o potrzebie rewizji strategii budowania autonomiczności Europy. Prelegent postulował przede wszystkim rozwijanie wspólpracy w ramach traktatowego mechanizmu stalej wspólpracy strukturalnej (PESCO). Podsumowując, zauważył iż „,albo Europa zgodzi się co do wspólnego interesu w polityce bezpieczeństwa, albo nowo kreujący się świat zapomni o Europie".

M. Cieniuch także uznał wywiązanie się dyskusji na temat relacji transatlantyckich w wyniku objęcia prezydentury przez D. Trumpa za czynnik pozytywny. Zauważył także. że ze względu na krótki czas sprawowania wladzy przez nową administrację oraz brak doświadczenia większości jej czlonków w polityce, dotychczasowe przewidywania na temat polityki zagranicznej USA sprowadzają się do spekulacji. W sferze militarnej nie zauważono dotychczas niepokojących sygnałów, wszystkie decyzje NATO (np. te podjęte podczas szczytu w Warszawie) sa sprawnie realizowane. M. Cieniuch przewiduje kontynuację w polityce bezpieczeństwa USA, co byłoby korzystne dla Europy oraz dla Polski. Za malo prawdopodobne uznal osiagnięcie przez wszystkie państwa NATO progu $2 \%$ PKB przeznaczanych na obronność w wyznaczonym terminie.

Dyskusja z udzialem publiczności dotyczyła mechanizmów wspólpracy na polu bezpieczeństwa w ramach UE (traktatowych, takich jak PESCO, oraz pozatraktatowych, np. „obronne Schengen”) oraz stosunków Polski z partnerami: Francją Niemcami i USA.

W ramach panelu drugiego podjęto dyskusję na temat wplywu stosunków amerykańskorosyjskich na sytuację w Europie Wschodniej, regionie Morza Czarnego i Azji Środkowej. 
Rolę moderatora pelnił Artur Gruszczak (UJ, ISS), zaś w dyskusji udział wzięli Robert Pszczel (Dyrektor Biura Informacyjnego NATO w Moskwie), Boris Tarasyuk (b. Minister Spraw Zagranicznych Ukrainy), Bogdan Klich (senator RP, b. Minister Obrony Narodowej), Akkan Suver (Marmara Group Foundation) oraz Istvan Gyarmati (ambasador, prezes International Centre for Democratic Transition).

R. Pszczel skoncentrowal się w swoim wystapieniu na przedstawieniu bieżacej dzialalności NATO, wymieniając inicjatywy będące $w$ trakcie realizacji i zauważając, iż nie odnotowano gwaltownego wplywu zmiany wladzy w USA na dzialalność Sojuszu. Podkreślał przede wszystkim fakt rozlokowania sił NATO na wschodniej flance. Odnosząc się do zobowiazania $2 \%$ PKB wydatków na obronność stwierdzil, iż wszystkie bez wyjątku państwa członkowskie Sojuszu będą musiały się z niego wywiązać.

B. Tarasyuk mówil przede wszystkim o Ukrainie. Sygnaly padające ze strony D. Trumpa na temat budowania porozumienia z Rosją były dla niego wysoce niepokojace. Bez względu jednak na nastawienie administracji amerykańskiej, Rosja stanowi wg niego zagrożenie dla regionu, oprócz Ukrainy przede wszystkim dla państw baltyckich. Doszukując się pozytywów doktryny „America first” D. Trumpa zauważył, iż być może jej realizacja będzie wymagala zahamowania ambicji Rosji. Zaangażowanie USA we wsparcie Ukrainy uznal jednak za niezbędne ze względu na ograniczone możliwości Francji i Niemiec.

B. Klich zaakcentował konieczność przejęcia większej odpowiedzialności za bezpieczeństwo przez Europę, wymieniając niemiecko-francuskie inicjatywy rozwijania WPBiO, które pojawily się po Brexicie. Sektor bezpieczeństwa uznał za potencjalnie dający możliwości przyspieszenia integracji europejskiej, jak zaznaczyl - w ramach istniejących przepisów traktatowych UE, czyli np. w ramach PESCO. Rozwijanie inicjatyw pozatraktatowych groziloby ich ekskluzywnością.

A. Suver skupil się na regionie Morza Czarnego, które, jak zauważyl, nie zamarza zimą i stanowi ważny strategiczny szlak wodny.

I. Gyarmati rozpoczal wystapienie od stwierdzenia, iż Zachód nie rozumie Rosji i w podobnym jak ona stopniu ponosi odpowiedzialność za wojnę na Ukrainie. Następnie krytycznie odniósł się do porozumienia Mińsk II, które nie powinno wedlug niego zostać zrealizowane ponieważ: 1) doprowadziłoby to do zniknięcia kwestii Krymu z agendy międzynarodowej; 2) jest niezbalansowne - od Rosji wymaga jedynie zaprzestana agresji, zaś od Ukrainy - radykalnej zmiany systemu konstytucyjnego; 3) nie jest poparte wiarygodnością Zachodu, zwlaszcza po wyborze D. Trumpa; 4) nieshusznie nadaje Rosji status równorzędny z NATO. Na temat Rosji stwierdzil, że jest ona „na tyle silna, na ile Zachód jej pozwala". I. Gyarmati nawiązał także do zmieniających się uwarunkowań - rosnącej roli Internetu i niepaństwowych aktorów międzynarodowych.

Dyskusja dotyczyla kwestii porozumienia Mińsk II i rozwijania WPBiO. Pogłębiano także temat dialogu z Rosją i rozważano pytanie - czy bezpieczeństwo Europy jest możliwe razem z, bez czy też przeciwko Rosji. 